\title{
Rapid movement of frozen debris-lobes: implications for permafrost degradation and slope instability in the south-central Brooks Range,
} Alaska

\author{
R. P. Daanen ${ }^{1}$, G. Grosse ${ }^{2}$, M. M. Darrow ${ }^{3}$, T. D. Hamilton ${ }^{4, *}$, and B. M. Jones ${ }^{4}$ \\ ${ }^{1}$ Water and Environmental Research Center, Institute of Northern Engineering, University of Alaska Fairbanks, Fairbanks, \\ Alaska, USA \\ ${ }^{2}$ Geophysical Institute, University of Alaska Fairbank, Fairbanks Alaska, USA \\ ${ }^{3}$ Mining and Geological Engineering Department, Institute of Northern Engineering, University of Alaska Fairbanks, \\ Fairbanks, Alaska, USA \\ ${ }^{4}$ US Geological Survey, Alaska Science Center, Anchorage, Alaska, USA \\ *Emeritus
}

Correspondence to: R. P. Daanen (rdaanen@alaska.edu)

Received: 8 August 2011 - Revised: 13 February 2012 - Accepted: 28 February 2012 - Published: 21 May 2012

\begin{abstract}
We present the results of a reconnaissance investigation of unusual debris mass-movement features on permafrost slopes that pose a potential infrastructure hazard in the south-central Brooks Range, Alaska. For the purpose of this paper, we describe these features as frozen debris-lobes. We focus on the characterisation of frozen debris-lobes as indicators of various movement processes using ground-based surveys, remote sensing, field and laboratory measurements, and time-lapse observations of frozen debris-lobe systems along the Dalton Highway. Currently, some frozen debrislobes exceed $100 \mathrm{~m}$ in width, $20 \mathrm{~m}$ in height and $1000 \mathrm{~m}$ in length. Our results indicate that frozen debris-lobes have responded to climate change by becoming increasingly active during the last decades, resulting in rapid downslope movement. Movement indicators observed in the field include toppling trees, slumps and scarps, detachment slides, striation marks on frozen sediment slabs, recently buried trees and other vegetation, mudflows, and large cracks in the lobe surface. The type and diversity of observed indicators suggest that the lobes likely consist of a frozen debris core, are subject to creep, and seasonally unfrozen surface sediment is transported in warm seasons by creep, slumping, viscous flow, blockfall and leaching of fines, and in cold seasons by creep and sliding of frozen sediment slabs. Ground-based measurements on one frozen debris-lobe over three years (2008-2010) revealed average movement rates of
\end{abstract}

approximately $1 \mathrm{~cm} \mathrm{day}^{-1}$, which is substantially larger than rates measured in historic aerial photography from the 1950s to 1980s. We discuss how climate change may further influence frozen debris-lobe dynamics, potentially accelerating their movement. We highlight the potential direct hazard that one of the studied frozen debris-lobes may pose in the coming years and decades to the nearby Trans Alaska Pipeline System and the Dalton Highway, the main artery for transportation between Interior Alaska and the North Slope.

\section{Introduction}

Climate change currently underway in the Arctic (ACIA, 2004; IPCC, 2007) is strongly affecting cryosphere dynamics and distribution, including warming and degradation of permafrost and reduction of its areal extent. Major impacts are observed in thermal conditions of near-surface permafrost and active layer (Romanovsky et al., 2002, 2007, 2010; Nolan et al., 2005; Kääb et al., 2007a; Jorgenson et al., 2006; Smith et al., 2010). Mountain permafrost is warming and retreating to higher elevations in response to climate change, and a similar response is recorded by diminishing glaciers (Nolan et al., 2005; Kääb et al., 2007a; Marchenko et al., 2007; Harris et al., 2009). 
To determine rates of permafrost change and resulting landscape dynamics, permafrost research over recent decades has increasingly focused on processes related to both the vertical and lateral movement of the ground as a result of transient temperature dynamics and phase change (Haeberli et al., 2006). Liquid water expansion upon freezing causes soil volume to increase and the soil surface to rise, whereas warming of the ground ice and phase change from a solid to liquid state causes loss of soil volume, structure and strength, resulting in greater susceptibility to erosion and mass wasting during thawing. The impact of soil strength reduction due to permafrost thawing is increased in mountainous settings where unconsolidated sediments exist, whereby slope destabilization may result in gravity-driven catastrophic downwasting (Kääb et al., 2005). Mass wasting features on permafrost-stabilized slopes have been researched extensively in many mountain regions (Wahrhaftig and Cox, 1959; Humlum, 1998b; Gorbunov and Seversky, 1999; Matsuoka et al., 2005; French, 2007; Gruber and Haeberli, 2007; Kääb et al., 2007b; Ikeda et al., 2008), allowing for the description and categorisation of many types of features with a unique set of characteristics. All have gravity in common as their driving force and many also share types of movement processes, such as sliding, flowing and creeping, typical for periglacial mountain regions (French, 2007).

In the European Alps, research has shown that degrading permafrost in bedrock regions causes hazards on steep slopes, in particular rock falls and landslides (Gruber and Haeberli, 2007). The number of rock falls and landslides greatly increases with increasing ground temperature, the loss of ice cement in bedrock cracks and pore space of rock debris, and the number of freeze-thaw transitions deeper in the rock face as mean annual ground temperatures approach the melting point of water. Higher substrate temperatures and liquid water released from ground ice results in decreased ground viscosity and slope stability. Slope stability is also a concern for permafrost-affected soils (Gude and Barsch, 2005; Lewkowicz and Harris, 2005; Harris et al., 2008b). Although ground ice slows the downslope movement of debris (Swanger and Marchant, 2007), warming atmospheric conditions can slowly degrade the ground ice, increasing the unfrozen water content in the ground, and releasing meltwater for increased pore water pressure and destabilizing slopes (Geertsema et al., 2006; Kääb et al., 2007b; Delaloye et al., 2008; Harris et al., 2008b; Ikeda et al., 2008; Roer et al., 2008; Lambiel et al., 2008).

Typical and dynamic permafrost-related mass wasting features on mountain slopes are rock glaciers, which are common in many cold climate regions (Barsch, 1977; Kääb et al., 1997; Humlum, 1998a, b; Isaksen et al., 2000; Berthling et al., 2003; Haeberli et al., 2006; Farbrot et al., 2007; Ballantyne et al., 2009; Brenning and Azocar, 2010). Rock glaciers generally consist of blocky debris (Wahrhaftig and Cox, 1959) with interstitial ice, although abundant fines have also been observed in these features (Ikeda and Matsuoka,
2006). A model for grain size distribution in rock glaciers is provided by Haeberli et al. (1998). The supply of debris to these features seems to control most of the movement on the order of centimetres to metres per year (Degenhardt, 2009), but other mechanisms such as warming result in rock glacier thinning are also described (Krainer and He, 2006; Roer et al., 2008; Ikeda et al., 2002).

Rock glaciers were recognised in Alaskan mountain ranges as early as the 1950s (Wahrhaftig and Cox, 1959), yet they remain understudied with respect to other mountain permafrost regions, likely due to limited access to the remote mountain areas and limited hazards to infrastructure. Wahrhaftig and Cox (1959) studied approximately 200 rock glaciers in the Alaska Range. Studies of the Fireweed rock glacier in the Wrangell Mountains have shown a movement rate of $3.5 \mathrm{~m}$ per year (Bucki et al., 2004; Bucki and Echelmeyer, 2004). In the Kigluaik Mountains on the Seward Peninsula, Calkin et al. (1998) report the presence of ten active tongue-shaped rock glaciers and, based on lichenometry, suggest that some of them formed about 3000$4000 \mathrm{yr}$ ago. In the Brooks Range, Calkin et al. (1987) found similar ages using lichen indicators, but they suggest that the initiation time coincided with the retreat of the Pleistocene glaciers in the region.

Although our frozen debris lobes resemble rock glaciers, in some respects, they differ in source area, composition and mechanism and rate of movement, as discussed below. We focus our study on permafrost-regulated, rapidly moving, elongate, partially frozen debris-lobes found on mountain slopes in the Brooks Range of Alaska. Although initially identified as active (Hamilton, 1978a, 1979b, 1981), others described these features as mostly inactive rock glaciers (Kreig and Reger, 1982; Brown and Kreig, 1983) and they have never been investigated in great detail. In this paper, we show for the first time that these features exhibit rapid movement, possibly linked to climate change and permafrost degradation, and may pose a hazard to nearby transportation infrastructure. The objectives of this paper are to characterise various processes that are typical for these landforms and assess the frozen debris-lobe dynamics over the last $60 \mathrm{yr}$, using (a) ground-based topographic surveys; (b) remote sensingbased analysis of lateral movements; (c) permafrost and active layer temperature measurements; (d) sedimentological and geotechnical analysis; and (e) tree ring analysis. We also describe the placement of frozen debris-lobes within the continuum of mass movement features. One particular frozen debris-lobe front is now very close $(<70 \mathrm{~m})$ to the Dalton Highway corridor; this individual feature poses a substantial hazard to the transportation infrastructure between Interior Alaska and hydrocarbon exploration and production centres of northern Alaska within the next few decades at current movement rates. 


\section{Study area}

The frozen debris-lobes we studied are located in the south-central Brooks Range of Alaska, USA. Based on historical repeat photography and lichenometry, Ellis and Calkin (1979) suggest that the most rapid retreat of alpine glaciers in the area occurred after ca. 1870, followed by a deceleration after the mid-1900s (Ellis and Calkin, 1984). Lake varves, in a glacially fed lake in the central Brooks Range, indicates that this portion of the Brooks Range has experienced atmospheric warming of 3.7 to $5.0^{\circ} \mathrm{C}$ during the summer months since the Little Ice Age as suggested by Bird et al. (2009) and by Evison et al. (1996), who studied glacial retreat dynamics. In a review paper, Molnia (2007) confirmed this overall pattern of glacial retreat since the late 19th century for the Brooks Range, which is in line with that of other Alaskan mountain ranges. Nolan et al. (2005) provide an overview of glacier thinning over the period from 1956 to 2003 for the McCall glacier northeast of our research area in the Brooks Range. They found an increase in thinning from $0.35 \mathrm{~m} \mathrm{yr}^{-1}$ before 1993 to $0.47 \mathrm{~m} \mathrm{yr}^{-1}$ thereafter.

Ellis and Calkin (1984) also suggest that rock glaciers, now present in cirques of the central Brooks Range, were probably initiated by increased mass wasting from oversteepened valleys and cirque walls after late glacial deglaciation. Ellis and Calkin (1979) report that most of the active rock glaciers are found north of the continental divide and at altitudes higher than $1350 \mathrm{~m}$. a.s.l., with lower limits for tongue-shaped rock glacier snouts at $1200 \mathrm{~m}$. a.s.l. for inactive forms and at $1300 \mathrm{~m}$. a.s.l. for active forms. Hamilton (1978a, b; 1979a, b; 1980, 1981) mapped the surficial geology of the central Brooks Range. He recognised and mapped a variety of mass wasting features in the region including rock glaciers, talus cones, rock slides, slush flow deposits as well as open system pingos, other frost mounds and aufeis, indicating groundwater flow. Using aerial photography and helicopter traverses, Hamilton was the first to map the location and widespread occurrence of lobate mass wasting features in the central Brooks Range that are distinct from the previously described rock glaciers, due to their material content, location, shape and vegetation cover. In his maps he named them flow slides.

Frozen debris-lobes FDL-A, -B and -C examined in this paper are located in the south-trending valley of the Dietrich River (Fig. 1), a short distance south of the Continental Divide. They are located near the Dalton Highway transportation corridor (see Fig. 1, lower inset), about $65 \mathrm{~km}$ north of Coldfoot and $170 \mathrm{~km}$ south of Deadhorse. Most of our detailed observations are from a frozen debris-lobe (site FDL-A) located at $67^{\circ} 48.669^{\prime} \mathrm{N} / 149^{\circ} 49.185^{\prime} \mathrm{W}$, which is also the frozen debris-lobe closest to the Dalton Highway. Based on a $0.5-\mathrm{m}$ resolution WorldView-1 satellite image from 24 August 2008 the lobe front was approximately $75 \mathrm{~m}$ away from the Dalton Highway and $310 \mathrm{~m}$ from the Trans
Alaska Pipeline System (TAPS), which is buried in alluvial sediment in this section. Paralleling the highway is the Dietrich River, which provides the main drainage for the region.

The study area is mapped as continuous permafrost (Jorgenson et al., 2008), however, permafrost in the valleys of the southern Brooks Range is relatively warm $\left(-1.0^{\circ} \mathrm{C}\right.$ at $24 \mathrm{~m}$ depth; measured in 2010) (CADIS, 2010) and shallow. Winter snow pack insulation causes warmer subsurface conditions relative to the air temperature. Combined, these characteristics result in permafrost that is highly susceptible to degradation and active layer deepening. Slope and aspect also contribute to the difference between warmer and cooler sites, with north facing slopes being predominantly cooler; this is evident from the altitudinal tree line, which varies strongly between slope aspects in this region. In addition, vegetation and presence or absence of soil organic layers is highly variable in the study area and strongly impacts the soil thermal regime. Deep borehole measurements indicate that the permafrost is generally warming in northern Alaska (Smith et al., 2010). Chandalar Shelf borehole temperatures, $30 \mathrm{~km}$ north of our research site, warmed about $0.04^{\circ} \mathrm{C} \mathrm{yr}^{-1}$ over the last two decades, which is similar to the Coldfoot deep borehole at $24 \mathrm{~m}$ depth.

\section{Methods}

\subsection{Field observations}

For this reconnaissance study, we collected data from frozen debris-lobes (FDL-A, -B, and -C) (see Fig. 1), with the majority of measurements taken on FDL-A. Field observations included an assessment of morphometric parameters such as overall shape, elevation, and slope and aspect configuration; identification and characterisation of surface features such as scarps, crevasses and vegetation cover; and identification of clear indicators for active movement such as toppling trees, split tree trunks, trees overrun and partially buried by the frozen debris-lobe, over-steepening of slopes, block fall of frozen, but otherwise unconsolidated fine-grained sediment, scratch marks on frozen blocks from sliding, and rippling and uplifting of frozen topsoil in front of the feature due to compression from the pressure of advancing debris.

Our field observations span multiple seasons (late winter: April; late summer: August) and the years 2008-2010. In the spring of 2008, we installed five metal marker pins near the terminus of FDL-A to measure movement rates with a Differential Global Positioning System (DGPS). During the summers 2008 and 2009, we repeated these location measurements to assess local movement rates. We also collected DGPS data in transects across FDL-A and along its boundaries, including the terminus and the headwall (Fig. 2b).

A time-lapse camera was installed to take photographs of the terminus of FDL-A at one-hour intervals throughout the 2009 summer. Ground temperature data loggers were 


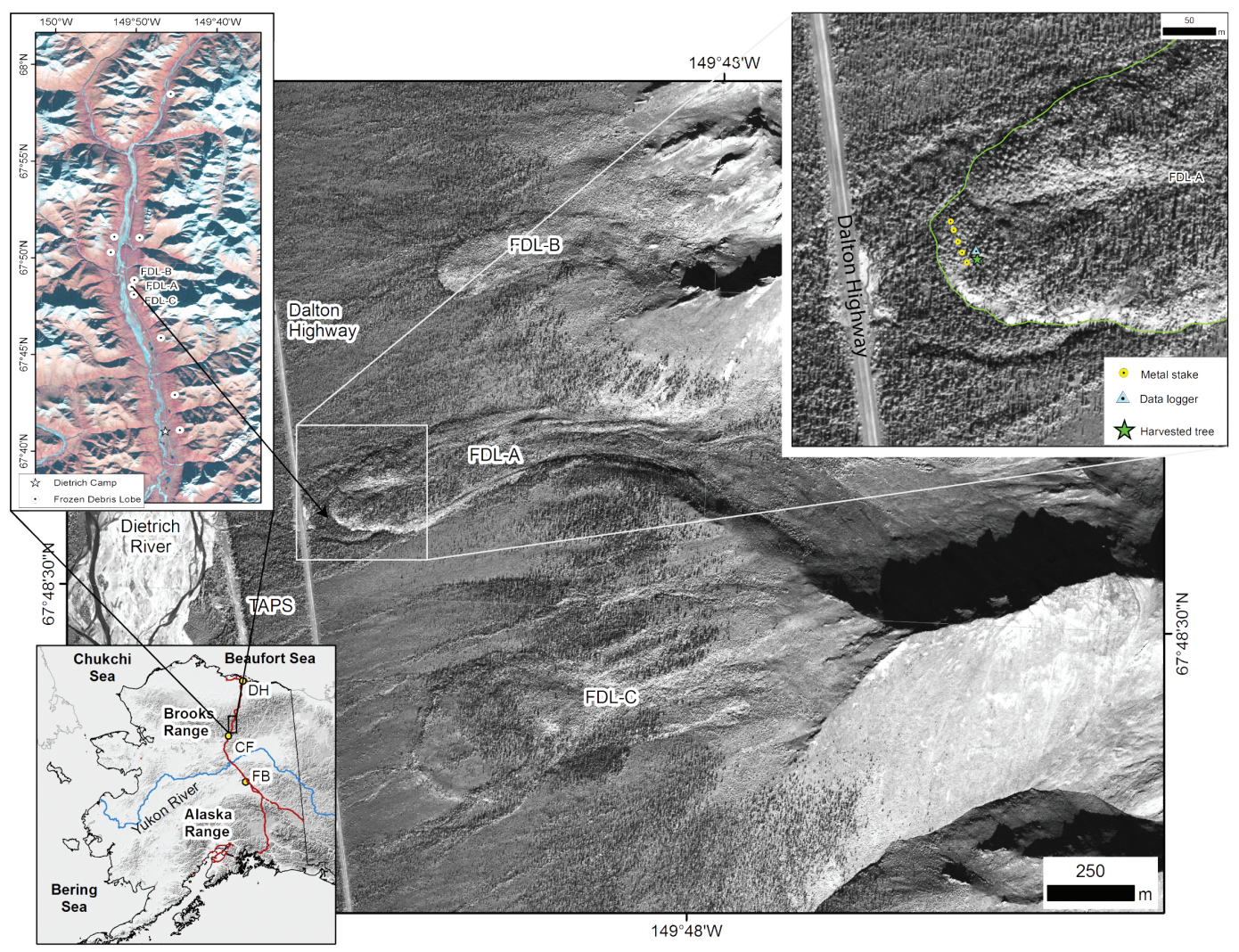

Fig. 1. Location of the study area and frozen debris-lobes (FDL) A, B and C (Image from 2008 WorldView-1, (C) Digital Globe). The Dietrich River, the TransAlaska Pipeline System (TAPS) and the Dalton Highway are shown to the west of the studied FDLs. Lower left inset indicates the study area (black rectangle) within the Brooks Range; FB is Fairbanks, CF is Coldfoot and DH is Deadhorse at the northern end of the Alaska Highway system (maroon line). Upper left inset shows the distribution of frozen debris-lobes along the Dalton Highway and this map is based on a Landsat-5 TM image (bands 4-3-2) from 19 September 2010 (USGS/NASA). Upper right inset shows the terminus of FDL-A with measurement locations.

installed to measure the air and surface temperatures, as well as the ground temperatures at depths of $0.50 \mathrm{~m}$ and $1.80 \mathrm{~m}$ on top of the feature near the terminus (near marker pin 1 (MP1); Fig. 1) and additionally in front of the terminus. We also collected two soil samples from the upper $1 \mathrm{~m}$ of FDL-A for grain size analysis and determination of soil plasticity, and harvested a living tree that grew on the frozen debris-lobe to analyse tree ring growth.

\subsection{Remote-sensing and terrain analysis}

We used high-resolution aerial and satellite data from 1955 , 1979 and 2008 to delineate the frontal terminus and sides of the three frozen debris-lobes in the study area (Table 1). All images were co-registered to the 2008 WorldView image and mapping was done in a desktop GIS environment. Additionally, we used a 5-m horizontal and 0.1-m vertical resolution, airborne interferometric synthetic aperture radar (IfSAR) derived digital elevation model (DEM) to assess the three-dimensional morphometry of the three features in our study area. The DEM was post-processed by removing all sinks and smoothing it with a $3 \times 3$ low pass filter. Once complete, we derived secondary parameters, including slope, aspect, planimetric and profile curvature, watershed size, and flow accumulation of the study area (Figs. 2 and 3).

\section{Results}

\subsection{Field observations}

The frozen debris lobes flow from mountain slopes (see Fig. 4), and consists of a mixture of coarse- to fine-grained debris (including woody debris from shrubs and trees where the frozen debris-lobes extend below forest limits). We also observed massive and interstitial ice within the frozen debrislobes. Most of these features are covered with stands of drunken spruce trees (see Fig. 4c), which alerted us to their movement and prompted our investigation into these features. Trees growing on the slopes of the frozen debrislobes experience great horizontal stress in the root zone due to ground movements, which can result in splitting of live 

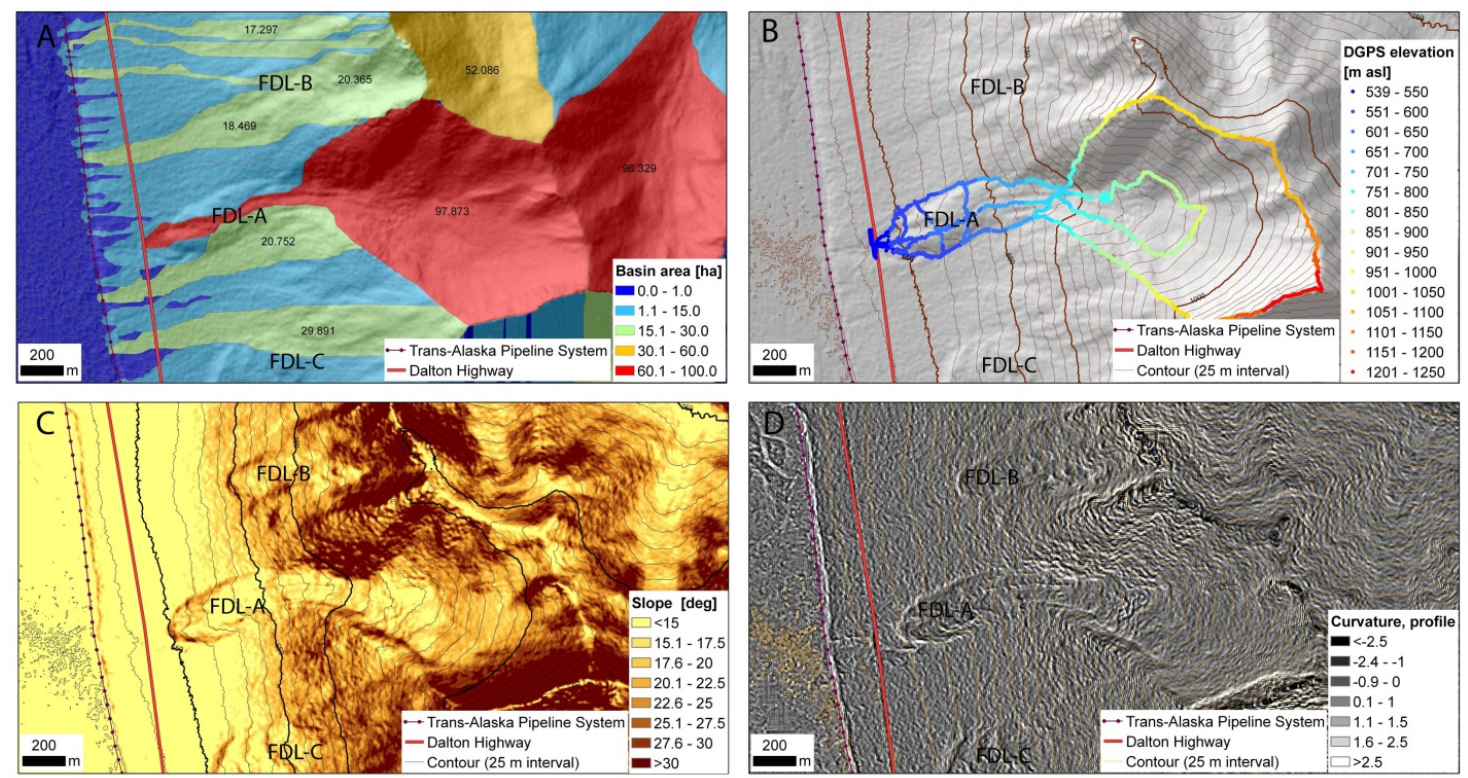

Fig. 2. IfSAR DEM-derived morphometric characteristics of frozen debris-lobe A (FDL-A). (a) Watershed area (ha) contributing to FDL-A (ca. 98 hectare); (b) shaded relief map with contour lines and an overlay of DGPS data, observed points are forming a line; (c) slope map; (d) curvature map.
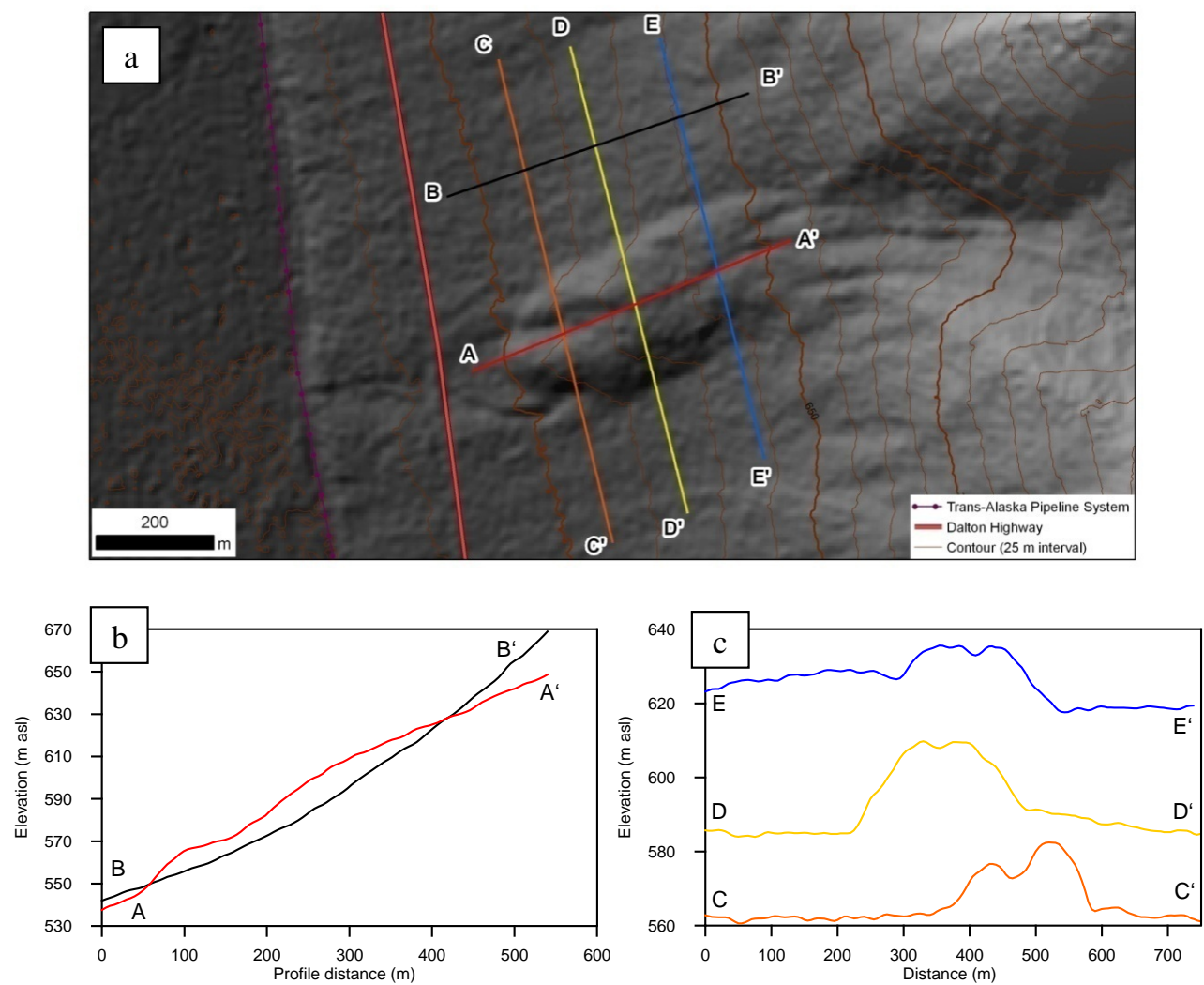

Fig. 3. Surface morphometry of frozen debris-lobe A (FDL-A). (a) Location of cross sections and long profiles; (b) long profiles, over FDL-A $\left(\mathrm{A}-\mathrm{A}^{\prime}\right)$, and next to FDL-A (B-B'); (c) three cross sections over FDL-A $\left(\mathrm{C}-\mathrm{C}^{\prime}, \mathrm{D}-\mathrm{D}^{\prime}\right.$, and $\left.\mathrm{E}-\mathrm{E}^{\prime}\right)$. 

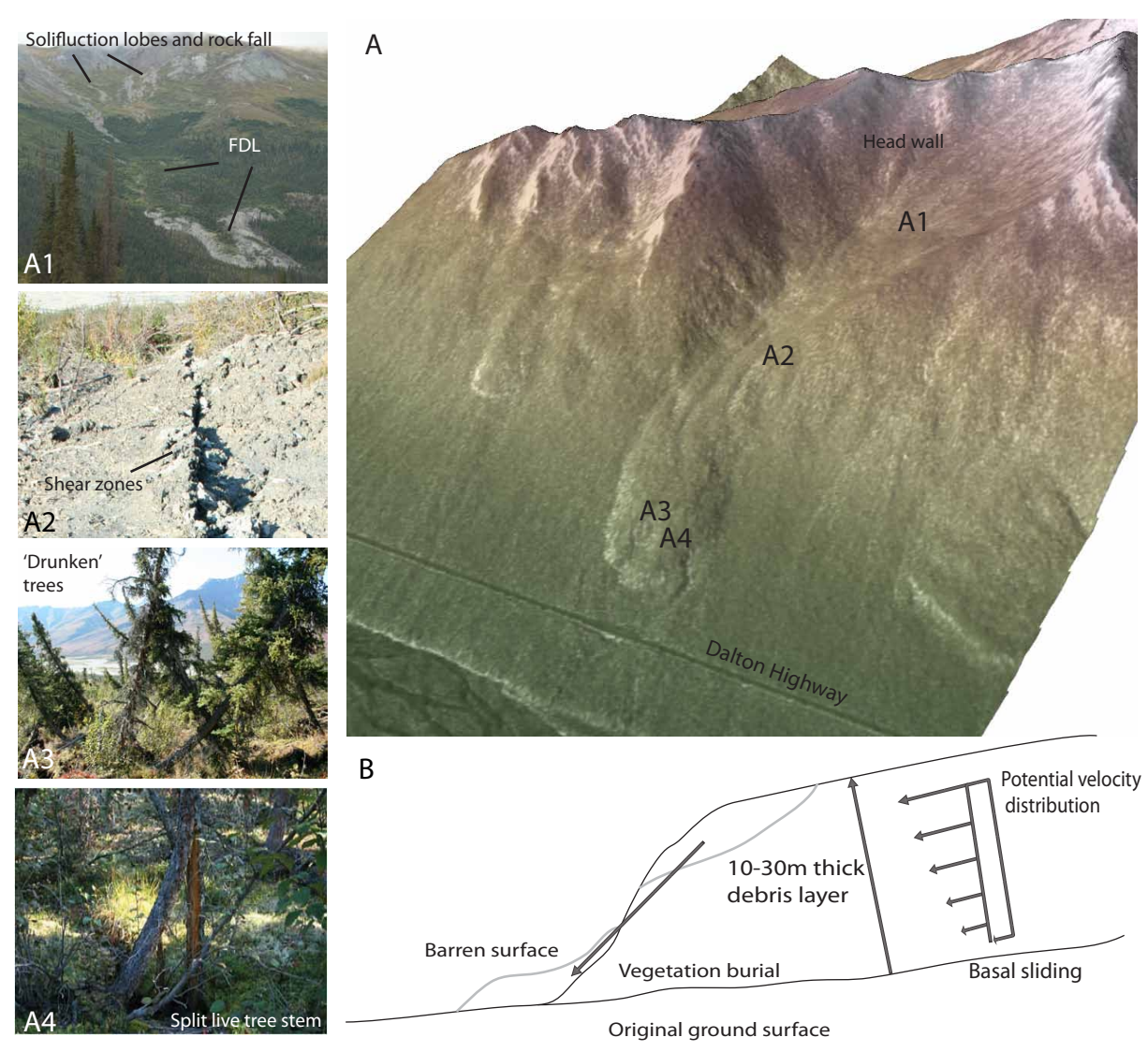

Fig. 4. Schematic overview of some observed processes on a frozen debris-lobe. (A1) Photograph of a frozen debris-lobe with upper zone of solifluction lobes, image shows FDL across the valley from FDL-A; (A2) shear zones in the middle section of FDL-A; (A3) "drunken" trees visible on FDL-A; (A4) split tree trunk on FDL-A; (B) profile of frozen debris-lobe front and associated movement; the flow vectors are assumed and parallel to the flow direction; background elevation model of FDL-A with upper contributing zone based on multiple DGPS surveys.

Table 1. Remote-sensing data used for mapping frozen debris-lobes.

\begin{tabular}{llllll}
\hline $\begin{array}{l}\text { Image type } \\
\text { (ID) }\end{array}$ & $\begin{array}{l}\text { Acquisition } \\
\text { date }\end{array}$ & $\begin{array}{l}\text { Ground } \\
\text { resolution }\end{array}$ & $\begin{array}{l}\text { Distance of FDL-A lobe } \\
\text { front to Dalton Highway(m)* }\end{array}$ & $\begin{array}{l}\text { Period } \\
(\mathrm{yr})\end{array}$ & $\begin{array}{l}\text { Front advance } \\
\text { rate }(\mathrm{m} \mathrm{yr}-1)\end{array}$ \\
\hline Aerial (AB1TAL00000009R_15_a) & 22 July 1955 & $1: 60000$ & $220 \mathrm{~m}$ & - & - \\
\hline Aerial (AR5790027841791) & 1 July 1979 & $1: 64000$ & $170 \mathrm{~m}$ & 24 & 2.1 \\
\hline $\begin{array}{l}\text { WorldView-1 (AUG08WV010000008 } \\
\text { AUG24220130_P1BS_052031425010_15_P003) }\end{array}$ & 24 August 2008 & $0.5 \mathrm{~m}$ & $70 \mathrm{~m}$ & 29 \\
\hline
\end{tabular}

* Distance was measured between the toe of the front lobe and the highway embankment toe; for the 1955 image, distance was measured to the location where the highway is currently located.

tree trunks (see Fig. 4d). Frozen debris-lobes are generally $500-$ to $2000-\mathrm{m}$ long and 50 - to $500-\mathrm{m}$ wide, with a riser height (elevation above surrounding soil) between 5 and $30 \mathrm{~m}$. Frozen debris-lobes move down slope from small drainage basins, typically less than $1 \mathrm{~km}^{2}$ (Fig. 2a). Frozen debris-lobes are often located in small valleys; these valleys may or may not have a headwall providing a source of debris due to intense frost weathering. Often, solifluction lobes can be found at higher elevations just above these features, providing an additional material source. In larger basins frozen debris-lobes are absent and debris accumulates as alluvial fans. 


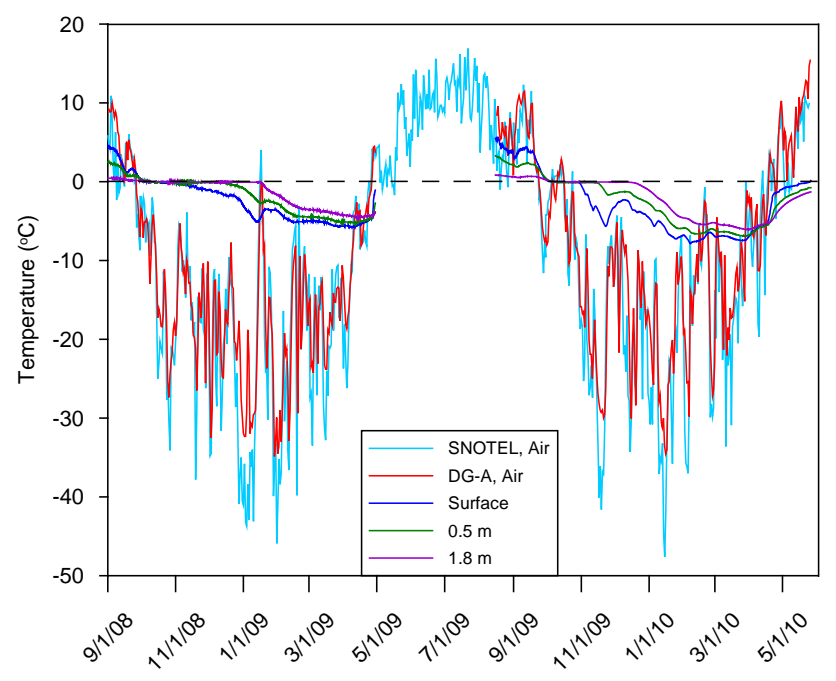

Fig. 5. Air and soil temperatures (surface, 0.5 and $1.8 \mathrm{~m}$ ) for FDLA.Air temperatures from the SNOTEL weather station in Coldfoot are included for comparison.

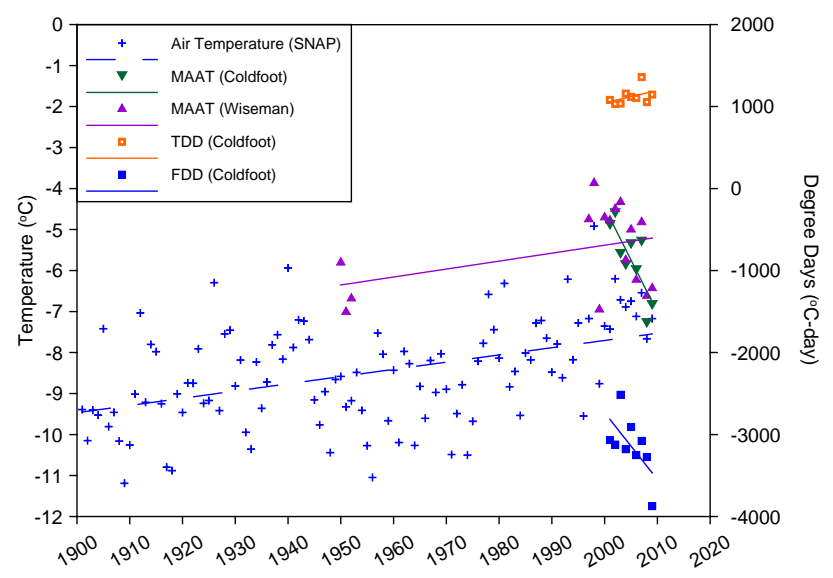

Fig. 6. Mean annual air temperature near FDL-A. Reanalysis data is from SNAP; measured data was taken from the SNOTEL site near Coldfoot (60 km south of FDL-A) and near Wiseman $(50 \mathrm{~km}$ south of FDL-A) (National Water and Climate Center, part of the Natural Resources Conservation service); thawing and freezing degree days are for Coldfoot.

Movement of frozen debris-lobes can be observed in the form of cracks in the surface of these features. These cracks are up to $25 \mathrm{~cm}$ wide, several metres deep and stretch over tens of metres laterally, and are often responsible for split tree trunks. Along the terminus of these features, trees are commonly overrun as the frozen debris-lobe advances. We observed live trees being pushed over and partially covered by flowing mud (summer) and by frozen debris slabs (winter). Frozen debris slabs slide over weak zones, and are observed during spring protruding out from the surface near steep slopes. In addition, frozen soil and debris slabs buckle in front of the frozen debris-lobes, forming cavities that collapse upon spring thaw. This formation seems to be the result of the feature pushing on the frozen soils in front of the lobe.

Active layer detachment slides and retrogressive thaw slumps are also observed on these features. Typically these features mobilize the sediments and accelerate the alluviation processes. Mobilization of the rocks was also observed from a steep section of the lobe terminus.

\subsection{Ground thermal regime}

To understand changes in ground temperature, we collected both ground and air temperatures on FDL-A (Fig. 5). The 2008-2009 mean annual air temperature is $-5.1^{\circ} \mathrm{C}$ and the mean annual ground temperature at a depth of $0.5 \mathrm{~m}$ in mineral soil is $-0.3{ }^{\circ} \mathrm{C}$. We compared these data to those from the Coldfoot Snow Telemetry (SNOTEL) site, which correlates strongly with a 2008-2009 mean annual air temperature of $-7.7^{\circ} \mathrm{C}$. The difference of $2.6^{\circ} \mathrm{C}$ is most likely due to atmospheric inversion with FDL-A 200 metres elevated over the valley floor where the SNOTEL site is located. Longterm changes in ground temperature are mostly a function of changes in mean annual air temperature. We compared the short record for mean annual air temperature in the region to climate reanalysis developed by the Scenarios Network for Alaska Planning (SNAP) (Fig. 6). This dataset was downscaled from multiple global circulation models (http://www.snap.uaf.edu). The short-term trend of decreasing mean annual air temperature measured near Coldfoot, Alaska appears contradictory to the regional warming trend in the long-term record and permafrost temperatures (Fig. 6). However, the trend in thawing degree days since 2001 indicates a warming trend for the region in summer, in spite of relatively cold winters.

Although the soil temperature dataset from FDL-A only spans two years, it provides some insights into the ground thermal regime. Soil temperatures collected on FDL-A indicate an active layer at least $1.8 \mathrm{~m}$ deep (see Fig. 5). Movement of FDL's causes debris exposure to the atmosphere, whereas nearby stable areas typically bear continuous cover of moss and tussocks, resulting in colder soil conditions. Additionally, the surface on these features is also much better drained, reducing the thermal offset.

\subsection{DGPS surveys}

The results of the marker pin survey on FDL-A with a DGPS demonstrated $1.3 \mathrm{~m}$ of movement during four months between April and August 2008, which indicates an average rate slightly greater than $1 \mathrm{~cm} \mathrm{day}^{-1}$. Repeat measurements in 2009 also showed a similar daily movement rate.

A survey of the entire feature during 2009 is presented in Fig. 2b. The DGPS was carried in a backpack while climbing over the feature. These data provide a snapshot of the geometry that can be compared with future datasets. 


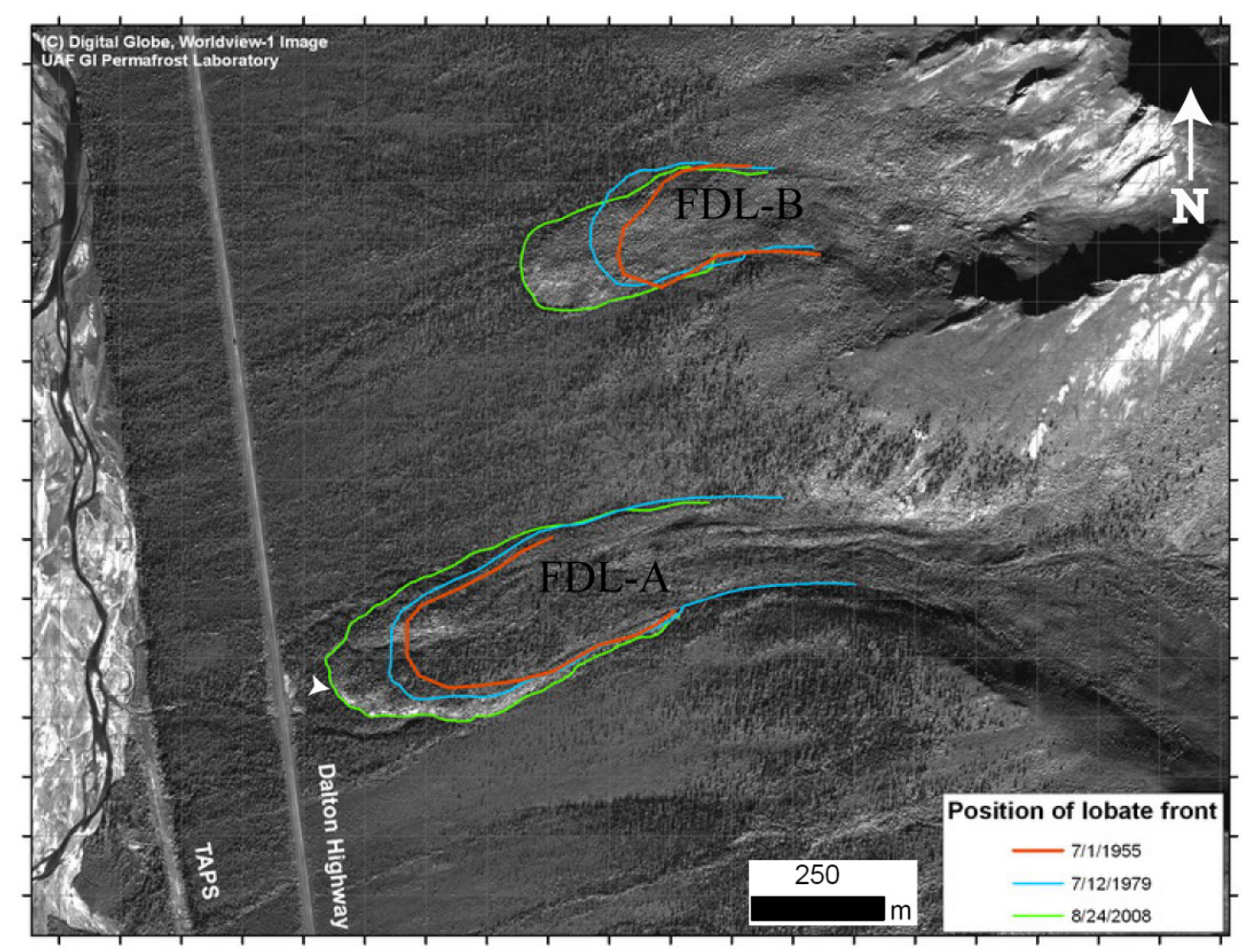

Fig. 7. Comparison of the termini positions of FDL-A and FDL-B between 1955 and 2008 from high-resolution aerial and satellite based remotely sensed imagery. Two drainage channels in front of the lobe drain FDL-A and are not part of the moving body. The white arrow near the terminus of FDL-A indicates the repeat photo camera location illustrated in Fig. 10.

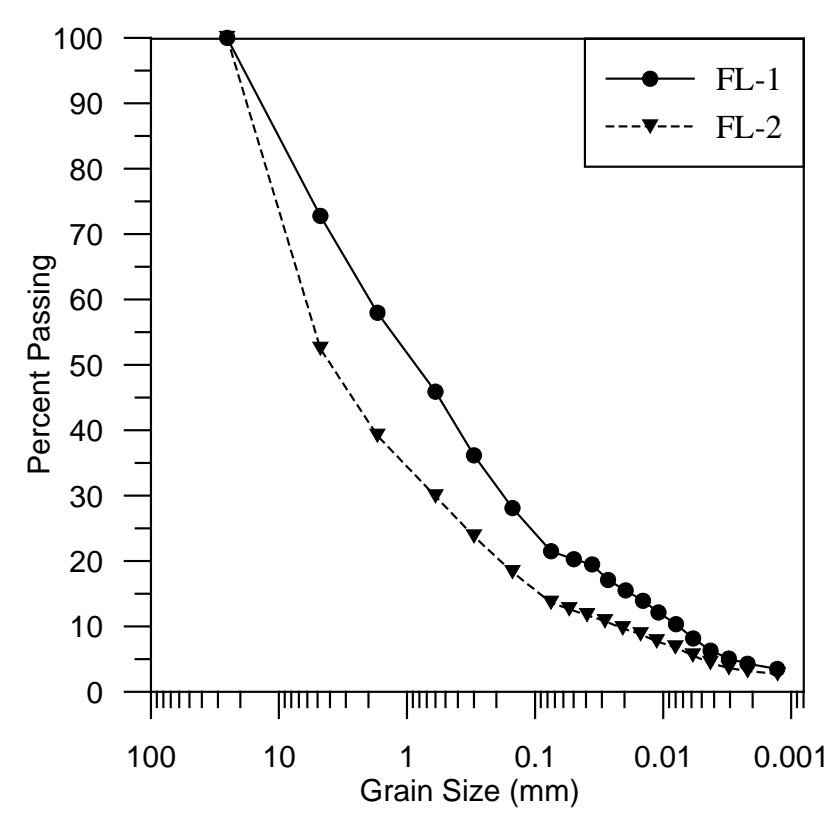

Fig. 8. Grain size distribution of two sediment samples taken from the top portion of the front lobe of FDL-A.

\subsection{Remote-sensing and terrain analysis}

FDL-A is elongate, varies in width from 140 to $260 \mathrm{~m}$ and has a length of $1200 \mathrm{~m}$ beyond its source area (Fig. 3). Based on the IfSAR DEM, the height of the front of this frozen debris-lobe above the surrounding area is $20 \mathrm{~m}$, rising to $25 \mathrm{~m}$ approximately $275 \mathrm{~m}$ behind (upslope) from the lobe front, and decreasing again to 10 to $18 \mathrm{~m}$ approximately $500 \mathrm{~m}$ behind the lobe front. This indicates that debris movement is episodic or pulse like, with periods of faster movement alternating with periods of stagnation and buildup. Such movement pulses likely are controlled by slope, ground temperature, liquid water content and debris supply. The slope of the surrounding area north and south of the frozen debris-lobe front ranges from $5^{\circ}$ to $17.5^{\circ}$ (Fig. 3). While the surface of the frozen debris-lobe has roughly the same slope along its long axis, multiple areas along the lobe front as well as its sides have slopes exceeding $30^{\circ}$, which agrees with field observations of steep and several metre high scarps. The entire watershed contributing to FDL-A is about 98 ha, one of the largest watersheds on this mountain slope (Fig. 2a). The lobe front, with its approximately 20-m height and 170-m width, advances a debris volume of about $34 \mathrm{~m}^{3} \mathrm{day}^{-1}\left(12410 \mathrm{~m}^{3} \mathrm{yr}^{-1}\right)$ at the current movement rate of $1 \mathrm{~cm} \mathrm{day}^{-1}$ observed with ground measurements between 


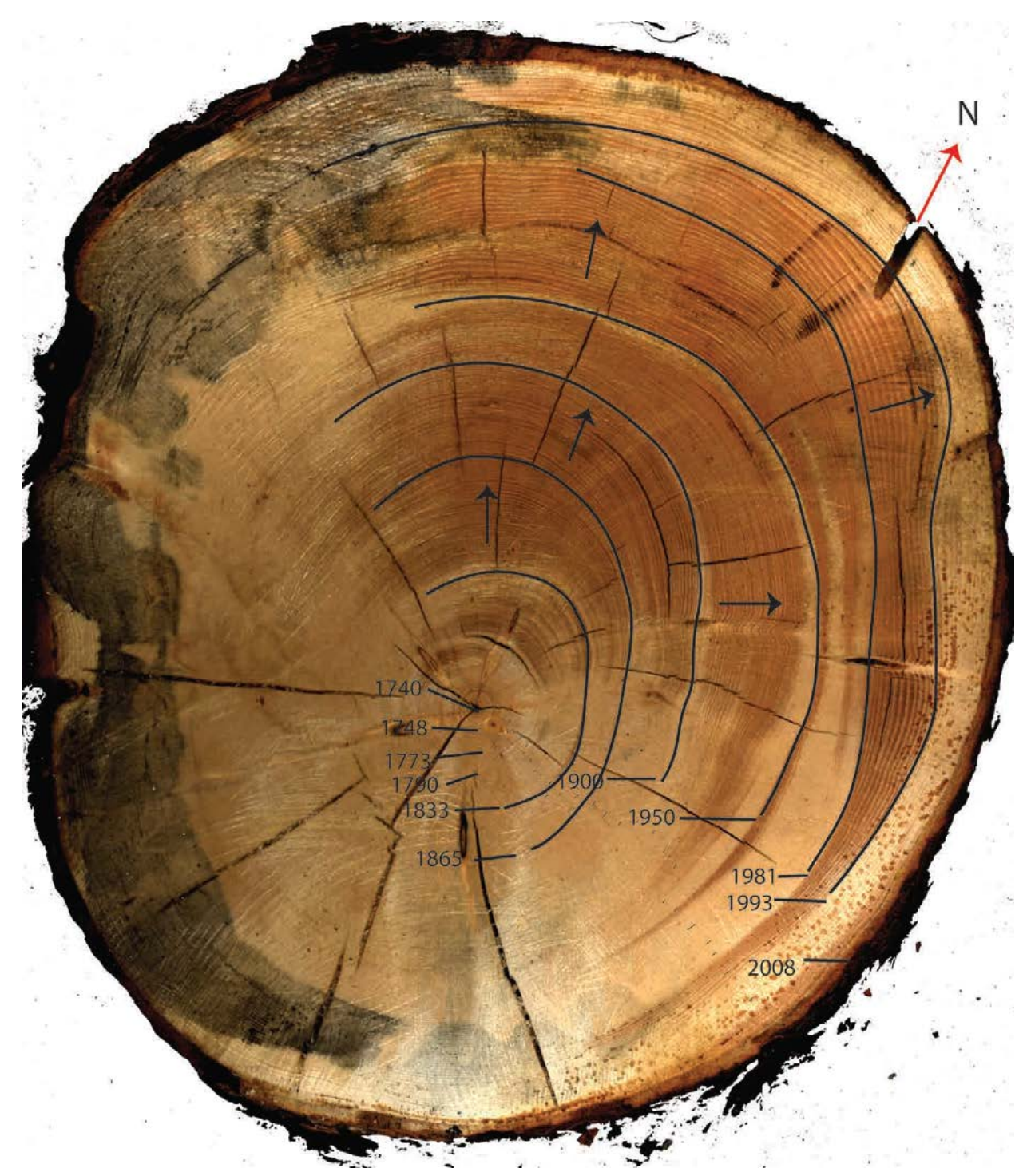

Fig. 9. Tree rings with compression wood direction shifts. The tree was harvested in 2008. Changes in the direction of compression wood growth (indicated by black arrows) occurred in the years indicated in the figure.

April and August 2008. Debris advancing every year at the lobe front equals about $22 \times 10^{6} \mathrm{~kg}$, or about 440 truckloads per year for a 50-ton dump truck.

Analysis of an optical image time series covering the period from 1955 to 2008 shows an increase in the rate of advance of the frontal lobe of FDL-A and FDL-B (Fig. 7). During the 1955-1979 period, FDL-A moved approximately $50 \mathrm{~m}$, which indicates an average rate of $2.1 \mathrm{~m} \mathrm{yr}^{-1}$. During the 1979-2008 period, the terminus advanced $100 \mathrm{~m}$, which indicates a higher average rate of $3.4 \mathrm{~m} \mathrm{yr}^{-1}$. The average movement rate for the entire observation record is $2.8 \mathrm{~m} \mathrm{yr}^{-1}$. The current (2009-2010) movement rate we measured in the field is just over $1 \mathrm{~cm} \mathrm{day}^{-1}\left(\sim 3.6 \mathrm{~m} \mathrm{yr}^{-1}\right)$, which may indicate an ongoing increase in the average move- ment rate. In summary, the front of FDL-A advanced $150 \mathrm{~m}$ since 1955 , is currently less than $70 \mathrm{~m}$ away from the Dalton Highway, has a base cross-sectional width of $170 \mathrm{~m}$, an average height of $20 \mathrm{~m}$, and an accelerating terminus movement rate of $1 \mathrm{~cm} \mathrm{day}^{-1}$.

\subsection{Debris composition}

Based on the geological map of the Chandalar Quadrangle by Brosgé and Reiser (1964), the bedrock immediately adjacent to the frozen debris-lobes in this reconnaissance study consists of slate, phyllite, schist, phyllitic siltstone, schistose sandstone and limestone. The frozen debris-lobes contained clasts of these rock types embedded in a complex fine grained matrix with massive and interstitial ice. We took two 


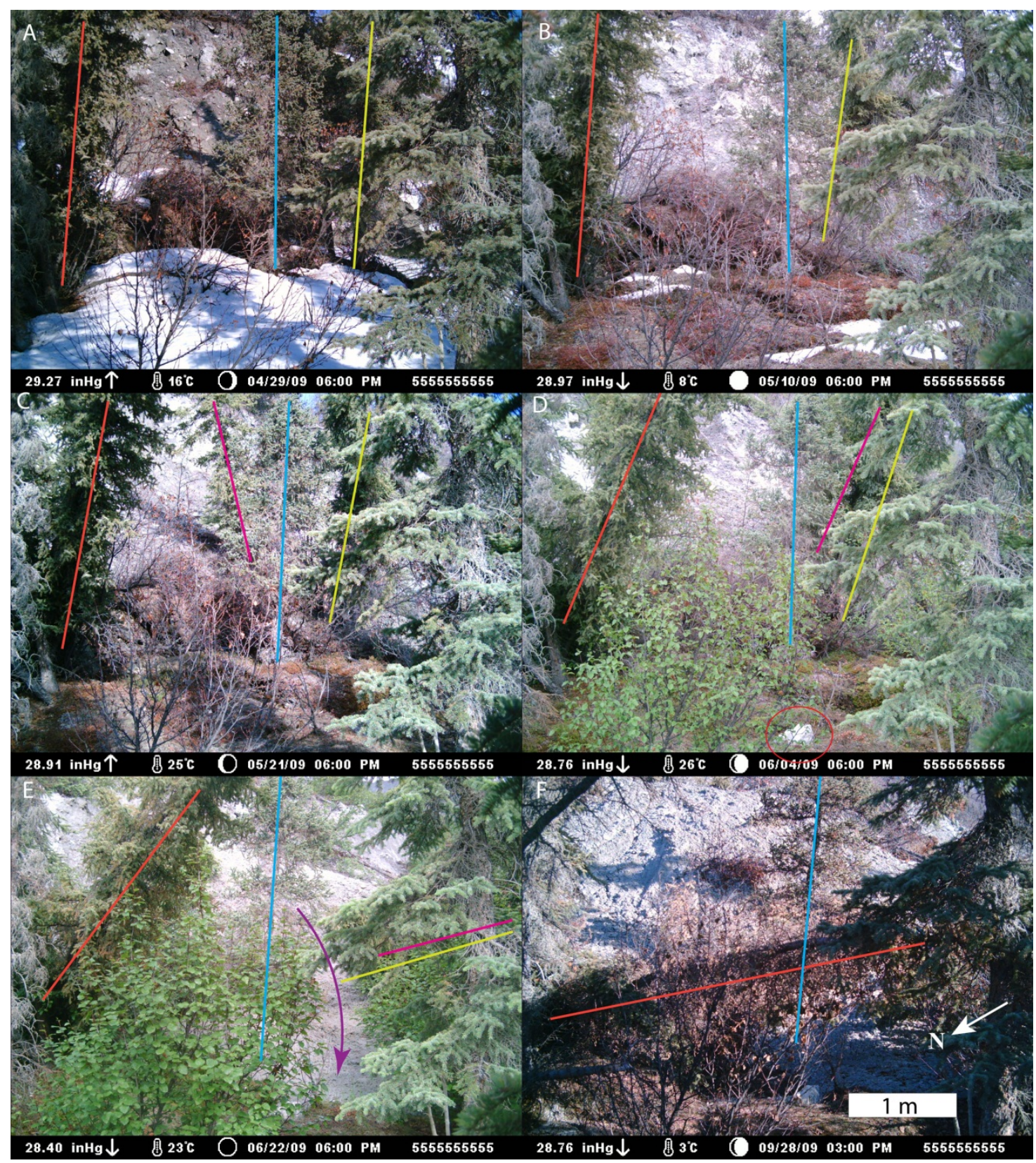

Fig. 10. Repeat photography of a portion of the FDL-A terminus. The steep face slumps down as it saturates during rain events. Straight lines follow positions of individual trees in the images (magenta tree fell from the top of the terminus); the red circle indicates the appearance of a rock from upslope; the purple arrow indicates mud flow from the steep slope. Photographs were selected from 29 April to 28 September 2009.

surface sediment samples from FDL-A, which included fistsized, tabular clasts of biotite garnet schist and quartz. Grain size analysis was performed for the sediment fraction smaller than $75 \mathrm{~mm}$. The two samples were classified as silty sand with gravel and silty gravel with sand (GM), according to the Unified Soil Classification System (Fig. 8). The sediment from these samples had a specific gravity of 2.79 , a liquid limit of 32 and no plastic limit.

\subsection{Tree ring analysis}

One unique aspect of the frozen debris-lobes in our study area is the presence of dense spruce and alder vegetation, due to their occurrence below the treeline. The tilted, or "drunken" trees (see Fig. 4c), may be a result of rapid movement and soil disturbance after a previous phase of stability that allowed tree growth, or a result of degrading permafrost and melting ground ice that also leads to surface disturbance 


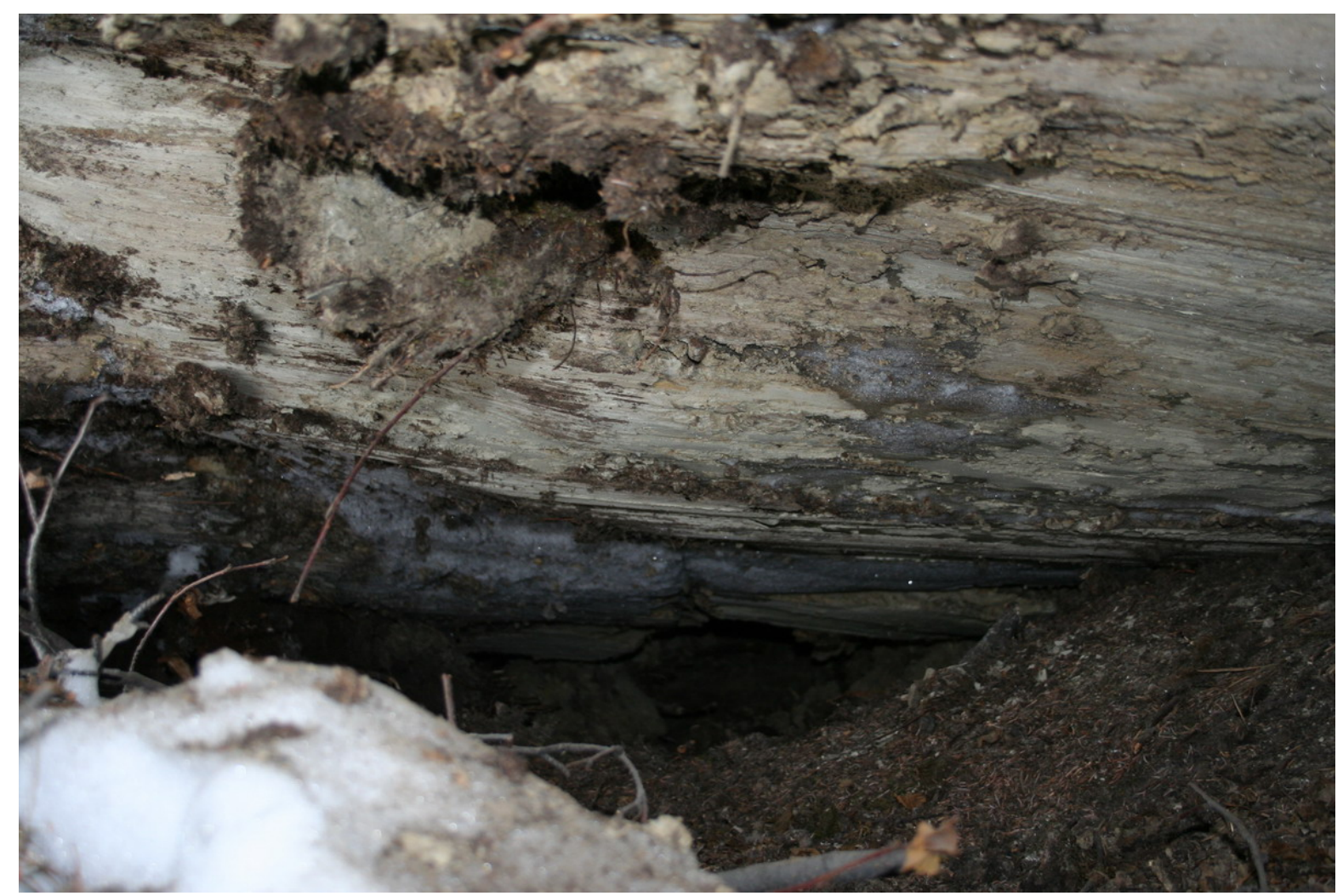

Fig. 11. Striations on the underside of a block of frozen silty debris indicate sliding motion in the frontal lobe of FDL-A during and after soil freezing. Below is the original ground surface, littered with recent organic matter, and above is the seasonally frozen ground that slid over the original ground. Ice can be seen in cracks as well as streaks on the underside from the sliding motion.

and irregular subsidence. The trees respond by growing additional wood on the leaning side of the tree in an attempt to maintain a vertical growth position. Tree ring analysis of one drunken spruce tree growing on the surface of FDL-A showed evidence of distinct shifts in direction rather than a continuous change in direction (Fig. 9). The tree rings indicated that this tree formed compression wood (i.e., larger tree rings on one side of the tree trunk) over periods ranging from one to four decades.

\subsection{Characterisation of movement processes in frozen debris-lobes}

The major types of movements observed at our studied frozen debris-lobes include: (1) permafrost creep during winter and summer, (2) basal sliding, and (3) several forms of active layer movement such as mudflows, detachment slides, gelifluction and sliding of frozen soil slabs during fall and early winter freezing. All forms of movement are driven by gravity and largely oriented in the same downslope direction. As a result of movement, deep crevasses or cracks occur within the frozen debris-lobe. These forms of movement also cause trees to lean and become buried under debris at the ter- minus, likely causing inclusion of considerable amounts of organic matter under and within the frozen debris-lobe.

Permafrost creep occurs in areas with steep gradients and is visualized in surface cracks and deformed trees (Fig. 2c). With the currently available data basal sliding was not directly observed, but indirect evidence suggests that it occurs. Organic soils, overrun by the frozen debris-lobe, could provide a weak layer that allows sliding as the weight of the debris pushes down the slope. Bucki and Echelmeyer (2004) identified such a sliding layer inside the Fireweed rock glacier. Other forms of sliding of the frozen debris in the active layer have been observed, such as in Fig. 11.

Downslope motion of seasonally frozen soil is common on steep terrain underlain by permafrost. A number of different movement types were observed in the field. During the summer of 2009, a steep portion of the terminus collapsed and caused a mudflow in front of the time-lapse camera. Beginning with the spring snowmelt, rapid movement of coarse debris and fine sediment occurs as mudflows from the terminus and the sides of the frozen debris-lobe. As the summer progresses and the active layer deepens, mudflows increase in size. Hourly time-lapse photographs revealed mudflows on FDL-A during or immediately after rain events, with rain 
water possibly contributing to the saturation of fine-grained sediments and leaching of fines from coarser debris (Fig. 10). From the images it is difficult to quantify rates of motion; however, the mudflow we measured exceeded $10 \mathrm{~m}$ in length in a single summer. The soil flows from the top of the steep terminus, likely driven by pore water pressure, to the base of the terminus where it accumulates. Pore water pressure builds as a result of snowmelt, rainfall and/or ground ice melt. Exposed frozen ground below the flowing soil contains both massive and interstitial ice, which may contribute to the mudflow as it melts during the summer. These mudflows cause erosion of frozen debris-lobes, and they add to alluviation along small creeks that flow into the Dietrich River and clog culverts underneath the Dalton Highway. At one location, $24 \mathrm{~km}$ south of the study area, an alluvial fan has recently formed directly downstream of a frozen debris-lobe. The alluvial fan is still mostly unvegetated, and may represent a case of frozen debris-lobe destabilization, further indicating the delicate balance between debris accumulation and debris erosion.

Detachment slides and retrogressive thaw slumps occur on steep parts of the sloping surfaces of frozen debris-lobes. Vegetation holds the upper weak layers together, where high liquid water content causes the upper layer to slide. At the upper end of the detachment slide a head wall remains that is sensitive to thaw slumping, because the ground ice is exposed to air temperatures. The overall flow of the frozen debrislobe causes the slope to change locally due to variations in velocity. Dynamic accumulation and depletion of debris occurs along the slope as a result of overall frozen debris-lobe movement.

Gelifluction in the active layer occurs mostly at a higher elevation where solifluction lobes deliver debris to the top of the frozen debris-lobe. These solifluction lobes can be observed on high resolution satellite images and at the ground surface.

Finally, during the fall and winter, we observed scour marks resulting from sliding motion that likely occurred during seasonal freezing. Several metres of the steepest sections of FDL-A's terminus moved by sliding during the fall, with entire frozen soil slabs overtopping the original ground surface and the movement causing the formation of scour marks along the base of the frozen soil slabs (Fig. 11).

The rates of movement of other frozen debris-lobes in the region vary. Some features appear to be stable, based on straight trees and older shrubs growing on the surface. Other features are becoming progressively more barren, as trees and shrubs are toppled and buried below a thick layer of debris. Thus, our preliminary findings reveal that frozen debrislobes are dynamic periglacial surface features that may exhibit local controls as well as regional responses to changes in climate and other types of disturbance.

\section{Discussion}

While frozen debris-lobes have been identified in the southcentral Brooks Range of Alaska, they may occur elsewhere. A feature of similar size and altitude which is also covered with trees, some with split trunks, was described by Blumstengel and Harris (1988) in the St. Elias Range. Blumstengel and Harris (1988) observed that the lower lobe terminus of the St. Elias feature is in the riverbed of the Slims River. Thus, damming of rivers and subsequent flooding are additional potential hazards associated with these features when they terminate in a river or alluviate the river bed.

\subsection{Movement of frozen debris-lobes}

Frozen debris-lobes exhibit a variety of soil motion processes in a continuum from gelifluction to permafrost creep (Haeberli et al., 2006). Large cracks in the surface of FDL-A suggest internal stresses due to heterogeneous movement. These cracks may be the result of internal movement of the frozen core rather than surface movement within the active layer (Matsuoka and Humlum, 2003; French, 2007). Based on the measured flow rate of frozen debris-lobes, basal sliding also should be considered as one of the processes causing motion. If basal sliding occurs, internal stresses can be expected as the centre of the feature would move more rapidly compared to the longitudinal edges of the debris-lobe due to differences in friction. Observations of soil surface deformation and buckling of vegetation in front of the terminus may be evidence of sliding. Some sliding at the surface occurs during freezing when the frozen soil slides as a rigid body over the unfrozen soil of the active layer (Fig. 11). This shearing may result from increased pore water pressure within the unfrozen portion of the active layer. This pressure may build during the fall as the freezing front penetrates the surface and confines ground water flow. Should increasing temperatures result in the development of a talik within a frozen debris-lobe, sliding or deformation in the talik may become the dominant and potentially catastrophic type of movement, when large parts of the frozen debris-lobe become unstable and slide down the slope.

Permafrost creep in these features is the suggested cause for surface deformation. This creep is also referred to as interstitial ice/debris flow (Haeberli et al., 2006), indicating its dependence on the presence and amount of interstitial ground ice. If creep occurs throughout the thick layer of frozen debris, it results in faster movement in the upper surface of these features. This type of motion leads to steepening slopes near the terminus of the feature that will increase the potential for mudflows when the frozen debris on the steep slopes thaws in spring.

Mudflows occur on the steepest slopes $\left(10-50^{\circ}\right)$ of the frozen debris-lobe surfaces and take place when the soils become oversaturated (Harris et al., 2008a), mainly during rain events in summer. Rapid warming of the soil surface can 
also cause oversaturation through melting of the pore ice. Mudflows were recorded with time-lapse photography and are best characterised by flowing of saturated debris. Trees were observed to slide down the terminus slope within an hour. Shrubs and trees were subsequently buried as they accumulated at the foot of the terminus. The overall slope $\left(5-10^{\circ}\right)$ of the surrounding ground, including the slope of the ground in front of the frozen debris-lobe, does not sustain the movement of mud and debris, causing it to accumulate near the toe of the terminus. A creek draining the feature, however, continues to carry the sediment to lower elevations towards the Dalton Highway and the Dietrich River.

Table 2 contains a summary of the postulated controls on the formation and behaviour of frozen debris-lobes, which are similar to those presented by Matsuoka et al. (2005). Ground ice plays a key part in the motion of creeping permafrost. We postulate that ice formation due to liquid water infiltration through surface cracks may be a major driving force contributing to the dynamic nature of frozen debrislobes. Underground ice forms or degrades with fluctuations in available energy sinks and sources. Climate is, therefore, a strong factor in the stability of frozen debris-lobes and will determine their shape and occurrence. During summer, a portion of this ground ice melts and, together with rain events, provides lubrication for soil movement through gelifluction (Lewkowicz and Harris, 2005; French, 2007; Harris et al., 2008b) and mudflows.

\subsection{Climate change effects}

Glacier dynamics have been directly linked to climate variation in the Brooks Range. Although very different in appearance and material, we mention them because of their sensitivity to regional changes in climate. Almost all glaciers in Alaska are losing mass due to climate warming (Calkin et al., 1998; Arendt et al., 2002, 2009; Nolan et al., 2005; Berthier et al., 2010). The movement rates of frozen debris-lobes are close to the movement rates reported for common glaciers in the Brooks Range (Nolan et al., 2005). Rock glaciers in contrast generally move at rates of millimetres to metres per year (Humlum, 1997; Roer et al., 2008; Haeberli et al., 2006; Krainer and He, 2006; Hausmann et al., 2007; Ikeda et al., 2008). Ikeda et al. (2008) suggested that climate change causes some rock glaciers to move at faster rates. Saturation of fine-grained sediments was identified as causing acceleration in rock glaciers (Roer et al., 2008; Kääb et al., 2007b; Ikeda et al., 2008; Riff et al., 2008). Warming summers with more potential for liquid water infiltration may have contributed to the acceleration observed in the European Alps. More precipitation throughout the year or an enhanced hydrological cycle is also projected for Interior Alaska, as a result of climate change (Huntington, 2006). We postulate that increased precipitation and, thus, runoff over and through a frozen debris-lobe and its watershed, may promote erosion and the formation of a talik within the frozen debris-lobe.
This allows for increased instability of frozen debris-lobes during the entire year, including the winter, and could result in movement rates far exceeding the rate of $1 \mathrm{~cm} \mathrm{day}^{-1}$ currently observed. This increased erosion rate may result in the release of massive amounts of sediment to areas in the valley below the frozen debris-lobe (i.e., the Dalton Highway and Dietrich River).

Tree-ring observations suggest that the movement rate of frozen debris-lobes is episodic, depending on long-term soil thermal behaviour, debris accumulation and short-term soil climate shifts. In particular inter-annual snow cover variation can play a major role in controlling those short-term variations due to the impact of snow cover on the ground thermal regime as an insulating layer.

The rate of movement of frozen debris-lobes in the southern Brooks Range has increased over the last $50 \mathrm{yr}$. Even though short-term records (decade), indicate a local cooling trend, the long-term records (century) indicate warming. Estimated climate effects on frozen debris-lobes are, at this point, mainly based on processes that we observed over a short time period. Ground temperature is expected to affect processes such as creep, gelifluction, sliding layers, talik formation and wetness. Warmer wetter ground is less viscous and greater pore pressure (enhanced by taliks) can reduce resistance between soil particles leading to potential sliding planes in the debris and deeper wetter active layers enhance frost action and gelifluction. Thus, these features may serve as an "early warning indicator" of general slope instability on hill slopes underlain by permafrost. However, longer time series and ground observations are necessary to better understand the relative importance of individual processes in FDL movement and vulnerability to acceleration.

\subsection{Frozen debris-lobe hazard}

Frozen debris-lobes constitute a potential hazard to the transportation corridor running through the Dietrich River valley. Large quantities of slope debris have accumulated over millennia in small contributing valleys. This debris has very likely remained frozen during the last few thousand years, because the region is underlain by continuous permafrost. We have found evidence that these features exhibit episodic movement and there is some evidence this movement is controlled by their internal thermal state.

Currently, the frozen debris-lobe closest to the Dalton Highway (FDL-A) poses the largest hazard to local infrastructure. Even though its terminus is currently located outside the highway right-of-way, the frozen debris-lobe is producing large amounts of sediment, which has already led to the burial of culvert inlets. At the very least, recent sediment alluviation associated with frozen debris-lobes is increasing maintenance costs for culverts along parts of the Dalton Highway system in the Brooks Range. In a worst case scenario, rapidly moving frozen debris-lobes could become a direct threat to the highway. Based on the observed 
Table 2. Controls on frozen debris-lobe(FDL) dynamics.

\begin{tabular}{|c|c|c|}
\hline Controls & Processes & Significance \\
\hline Bedrock & $\begin{array}{l}\text { Debris source; controls size, shape, } \\
\text { and abundance of rock debris }\end{array}$ & $\begin{array}{l}\text { Rock abundance controls FDL size; } \\
\text { platy debris promotes internal sliding }\end{array}$ \\
\hline Weathering & $\begin{array}{l}\text { Produces fine-grained rock material } \\
\text { (regolith) for incorporation into FDL }\end{array}$ & $\begin{array}{l}\text { Fine-grained debris holds moisture, } \\
\text { promoting ice-rich permafrost and internal FDL } \\
\text { creep }\end{array}$ \\
\hline Position on valley side & $\begin{array}{l}\text { Catchments above limits of last } \\
\text { glaciation are strongly weathered, } \\
\text { with incorporation of eolian silt and } \\
\text { organic soil material }\end{array}$ & $\begin{array}{l}\text { Promotes nourishment of FDL and robust } \\
\text { FDL movement }\end{array}$ \\
\hline Catchment geometry & $\begin{array}{l}\text { Shape, size, and slope of catchment } \\
\text { controls amount and rate of debris } \\
\text { fed into FDL }\end{array}$ & Affects size, shape, and flow rate of FDL \\
\hline Climate and climate change & $\begin{array}{l}\text { Affects permafrost stability, depth of } \\
\text { active layer, and water influx from } \\
\text { precipitation and snowmelt runoff }\end{array}$ & $\begin{array}{l}\text { Influences growth of massive ground ice } \\
\text { and interstitial ice; deeper active layer } \\
\text { with warming climate promotes surface } \\
\text { movements; warming permafrost } \\
\text { promotes internal movements }\end{array}$ \\
\hline Vegetation & $\begin{array}{l}\text { Roots stabilize FDL surfaces; } \\
\text { vegetation shades surfaces in } \\
\text { summer }\end{array}$ & $\begin{array}{l}\text { Inhibits surface erosion by preventing rain } \\
\text { impact and runoff; vegetation canopy and } \\
\text { ground cover maintain cooler surfaces and } \\
\text { near-surface permafrost }\end{array}$ \\
\hline
\end{tabular}

rate of motion of FDL-A, the timing of this potential hazard will likely occur within the next $20 \mathrm{yr}$ if the current rate is maintained. However, the question remains whether FDLA's movement rate can further increase undercurrent or future climatic, permafrost and hydrological conditions to the very fast rates of comparable slope features observed in other regions of the world (Kääb et al., 2005). In this case, direct impacts on the Dalton Highway may be only years away.

Currently there are more than ten FDL's identified along the transportation corridor and hundreds in the south central Brooks Range (Hamilton and Labay, 2012). The pipeline is in many cases further removed from the direct impact of FDLs, because it is located closer to the centre of the valley and often buried in this region. More detailed monitoring of FDL's in the Brooks Range transportation corridor would provide very useful data and information to land managers, transportation planners and infrastructure engineers, allowing a better assessment of existing and potential hazards to a safe and continuous operation of the Dalton Highway, TAPS and any planned future infrastructure in this region.

\section{Conclusions}

Frozen debris-lobes are wide-spread on mountain slopes in the south-central Brooks Range. These features are active and can move at rates greater than $1 \mathrm{~cm}$ day $^{-1}$. Their movement is a combination of creep, sliding and flow. They consist of frozen and unfrozen fine- to coarse-grained debris, as well as organic fine and coarse woody matter.

The location of a frozen debris-lobe (FDL-A) within $70 \mathrm{~m}$ of the Dalton Highway and close to the Trans Alaska Pipeline System is a concern because of the potential amount of sediment and debris that may impede travel along the Dalton Highway as well as access to TAPS. If current movement rates of this frozen debris-lobe are maintained, the feature will reach and seriously disturb the only road to the Alaska North Slope oil and gas fields in about $20 \mathrm{yr}$.

An observed acceleration of movement over the last $30 \mathrm{yr}$ is likely related to active layer deepening and permafrost warming as a result of changes in climate. Climate projections for Interior Alaska point to the increased warming, slope destabilization and, thus, hazard potential by these features over the coming years.

While providing us with insight into the overall characteristics and movement of frozen debris-lobes, the results of this reconnaissance-level investigation remain preliminary. Further research is necessary to better understand the 
internal stratigraphy and seasonal behaviour of frozen debrislobes, in particular, ice content, liquid water content and seasonal movement rates. In addition to continuing field observations and remote-sensing analysis, we suggest utilising geophysical methods and employing a drilling programme in future investigations.

Acknowledgements. We would like to thank Wilfried Haeberli and Bernd Etzelmüller for their reviews of this paper. The 2008 reconnaissance study of frozen debris-lobes was supported by the Alaska Experimental Programme to Stimulate Competitive Research (EPSCoR) programme with funds awarded to R. P. Daanen. Differential Global Positioning System data from 2008 was partially collected with a device from UNAVCO, a science support consortium, which is supported by National Science Foundation. High resolution satellite data and an IfSAR DEM were provided by the US Geological Survey, Alaska Science Center. Any use of trade, product, or firm names is for descriptive purposes only and does not imply endorsement by the US Government.

Edited by: A. Günther

Reviewed by: W. Haeberli and B. Etzelmüller

\section{References}

ACIA: Impacts of a Warming Arctic. Arctic Climate Impact Assessment (Highlights), Cambridge University Press, Cambridge, 110 pp., 2004

Arendt, A. A., Echelmeyer, K. A., Harrison, W. D., Lingle, C. S., and Valentine, V. B.: Rapid wastage of Alaska glaciers and their contribution to rising sea level, Science, 297, 382-386, 2002.

Arendt, A. A., Walsh, J., and Harrison, W.: Changes of Glaciers and Climate in Northwestern North America during the Late Twentieth Century, J. Climate, 22, 4117-4134, doi:10.1175/2009jcli2784.1, 2009.

Ballantyne, C. K., Schnabel, C., and Xu, S.: Exposure dating and reinterpretation of coarse debris accumulations ('rock glaciers') in the Cairngorm Mountains, Scotland, J. Quaternary Sci., 24, 19-31, doi:10.1002/Jqs.1189, 2009.

Barsch, D.: Nature and importance of mass-wasting by rock glaciers in alpine permafrost environments, Earth Surf. Process., 2, 231-245, 1977.

Berthier, E., Schiefer, E., Clarke, G. K. C., Menounos, B., and Remy, F.: Contribution of Alaskan glaciers to sea-level rise derived from satellite imagery, Nature Geosci., 3, 92-95, doi:10.1038/Ngeo737, 2010.

Berthling, I., Etzelmüller, B., Eiken, T., and Sollid, J. L.: The Rock Glaciers on Prins Karls Forland: Corrections of Surface Displacement Rates, Permafrost Periglac., 14, 291-293, 2003.

Bird, B., Abbott, M., Finney, B., and Kutchko, B.: A 2000 year varve-based climate record from the central Brooks Range, Alaska, J. Paleolimnol., 41, 25-41, doi:10.1007/s10933-0089262-y, 2009.

Blumstengel, W. and Harris, S. A.: Observations on an Active Lobate Rock Glacier, Slims River Valley, St. Elias Range, Canada, Fifth International Conference on Permafrost, 1, 689-695, 1988.

Brenning, A. and Azocar, G. F.: Statistical Analysis of Topographic and Climatic Controls and Multispectral Signatures of
Rock Glaciers in the Dry Andes, Chile (27 degrees-33 degrees S), Permafrost Periglac., 21, 54-66, doi:10.1002/ppp.670, 2010.

Brosgé, W. P. and Reiser, H. N.: Geology Map and section of the Chandalar Quadrangle, Alaska, Open File Report I-375, US Geological Survey, Miscellaneous Field Studies Map, Washington D.C., 1964.

Brown, J. and Kreig, R. A.: Guidebook to permafrost and related features along the Elliott and Dalton Highways, Fox to Prudhoe Bay, Alaska, Alaska Division of Geological and Geophysical Surveys Guidebook, 230 pp., 1983.

Bucki, A. K., Echelmeyer, K., and MacInnes, S.: The thickness and internal structure of Fireweed rock glacier, Alaska, USA., as determined by geophysicalmethods, J. Glaciology, 50, 67-75, 2004.

Bucki, A. K. and Echelmeyer, K. A.: The flow of Fireweed rock glacier, Alaska, USA, J. Glaciol., 50, 76-86, 2004.

CADIS, Coldfoot data 2010: http://aoncadis.ucar. edu/download/fileDownload.htm?fileAccessPointId= 6133a02a-51bb-4f19-8450-89d9456535f1, 2010.

Calkin, P. E., Haworth, L. A., and Ellis, C. J.: Rock Glaciers of Central Brooks Range, Alaska, U.S.A., in: Rock Glaciers, edited by: Giardino, J. R., Shroder, J. F., and Vitek, J. D., Allen and Unwin, Boston, 65-82, 1987.

Calkin, P. E., Kaufman, D. S., Przybyl, B. J., Whitford, W. B., and Peck, B. J.: Glacier regimes, periglacial landforms, anti Holocene climate change in the Kigluaik Mountains, Seward Peninsula, Alaska, USA, Arctic Alpine Res., 30, 154-165, 1998.

Degenhardt, J. J.: Development of tongue-shaped and multilobate rock glaciers in alpine environments - Interpretations from ground penetrating radar surveys, Geomorphology, 109, 94-107, doi:10.1016/j.geomorph.2009.02.020, 2009.

Delaloye, R., Perruchoud, E., Avian, M., Kauffman, V., Bodin, X., Hausmann, H., Ikeda, A., Kääb, A., Kellerer-Pirklbauer, A., Krainer, K., Lambiel, C., Mihajlovic, D., Staub, B., Roer, I., and Thibert, E.: Recent Interannual Variations of Rockglacier Creep in the European Alps. Ninth International Conference On Permafrost Institute of Northern Engineering, University of Alaska Fairbanks, Fairbanks, 1, 343-348, 2008.

Ellis, J. M. and Calkin , P. E.: Nature and Distribution of Glaciers, Neoglacial Moraines, and Rock Glaciers, East-Central Brooks Range, Alaska, Arct. Antarct. Alpine Res., 11, 403-420, 1979.

Ellis, J. M. and Calkin, P. E.: Chronology of Holocene Glaciation, Central Brooks Range, Alaska, Geol. Soc. Am. Bull., 95, 897912, 1984.

Evison, L. H., Calkin, P. E., and Ellis, J. M.: Late-Holocene glaciation and twentieth-century retreat, northeastern Brooks Range, Alaska, Holocene, 6, 17-24, 1996.

Farbrot, H., Etzelmüller, B., Guomundsson, A., Humlum, O., Kellerer-Pirklbauer, A., Eiken, T., and Wangensteen, B.: Rock glaciers and permafrost in Trollaskagi, northern Iceland, Zeitschrift Fur Geomorphologie, 51, 1-16, doi:10.1127/03728854/2007/0051S2-0001, 2007.

French, H. M.: The periglacial environment, third ed., Wiley, Chichester, West Sussex, 2007.

Geertsema, M., Clague, J. J., Schwab, J. W., and Evans, S. G.: An overview of recent large catastrophic landslides in northern British Columbia, Canada, Eng. Geol., 83, 120-143, doi:10.1016/j.enggeo.2005.06.028, 2006.

Gorbunov, A. P. and Seversky, E. V.: Solifluction in the mountains 
of central Asia: Distribution, morphology, processes, Permafrost Periglac., 10, 81-89, 1999.

Gruber, S. and Haeberli, W.: Permafrost in steep bedrock slopes and its temperature-related destabilization following climate change, J. Geophys. Res.-Earth, 112, F02s18, doi:10.1029/2006jf000547, 2007.

Gude, M. M. and Barsch, D.: Assessment of geomorphic hazards in connection with permafrost occurrence in the Zugspitze area (Bavarian Alps, Germany), Geomorphology, 66, 85-93, 2005.

Haeberli, W., Hoelzle, M. Kääb, A., Keller, F., Von der Mühll, D., and Wagner, S.: Ten years after drilling through the permafrost of the active rock glacier Murtèl, eastern Swiss Alps: answered questions and new perspectives. Proceedings of the Seventh International Conference on Permafrost, Yellowknife, Canada, Collection Nordicana, 57, 403-410, 1998.

Haeberli, W., Hallet, B., Arenson, L., Elconin, R., Humlun, O., Kääb, A., Kaufmann, V., Ladanyi, B., Matsuoka, N., Springman, S., and Von der Mühll, D.: Permafrost creep and rock glacier dynamics, Permafrost Periglac., 17, 189-214, doi:10.1002/ppp.561, 2006.

Hamilton, T. D.: Surficial geologic map of the Chandalar quadrangle, Alaska: U.S. Geological Survey Miscellaneous Field Studies Map MF-878A, scale 1:250 000, 1978a.

Hamilton, T. D.: Surficial geologic map of the Philips Smith Mountains quadrangle, Alaska: US Geological Survey Miscellaneous Field Studies Map MF879A, scale 1:250 000, 1978 b.

Hamilton, T. D.: Surficial geologic map of the Chandler Lake Quadrangle, Alaska: U. S. Geological Survey Miscellaneous Field Studies Map MF-1121, scale 1:250 000, 1979a.

Hamilton, T. D.: Surficial geologic map of the Wiseman quadrangle, Alaska: U. S. Geological Survey Miscellaneous Field Studies Map MF-1122, scale 1:250 000, 1979b.

Hamilton, T. D.: Surficial geologic map of the Killik River quadrangle, Alaska: US Geological Survey Miscellaneous Field Studies Map MF-1234, scale 1:250 000, 1980.

Hamilton, T. D.: Surficial geologic map of the Survey Pass quadrangle, Alaska: U. S. Geological Survey Miscellaneous Field Studies Map MF-1320, scale 1:250 000, 1981.

Hamilton, T. D. and Labay, K. A.: Surficial geologic map of the Gates of the Arctic National Park and Preserve, Alaska: U. S. Geological Survey Scientific Investigations Map 3125, scale 1:300 000, 2012.

Harris, C., Kern-Luetschg, M., Murton, J., Font, M., Davies, M., and Smith, F.: Solifluction Processes on Permafrost and Nonpermafrost Slopes: Results of a Large-scale Laboratory Simulation, Permafrost Periglac., 19, 359-378, doi:10.1002/Ppp.630, 2008a.

Harris, C., Smith, J. S., Davies, M. C. R., and Rea, B.: An investigation of periglacial slope stability in relation to soil properties based on physical modelling in the geotechnical centrifuge, Geomorphology, 93, 437-459, 2008b.

Harris, C., Arenson, L. U., Christiansen, H. H., Etzemüller, B., Frauenfelder, R., Gruber, S., Haeberli, W., Hauck, C., Holzle, M., Humlum, O., Isaksen, K., Kääb, A., Kern-Lutschg, M. A., Lehning, M., Matsuoka, N., Murton, J. B., Nozli, J., Phillips, M., Ross, N., Seppala, M., Springman, S. M., and Von der Mühll, D.: Permafrost and climate in Europe: Monitoring and modelling thermal, geomorphological and geotechnical responses, EarthSci. Rev., 92, 117-171, doi:10.1016/j.earscirev.2008.12.002,
2009.

Hausmann, H., Krainer, K., Brückl, E., and Mostler, W.: Internal structure and ice content of Reichenkar rock glacier (Stubai Alps, Austria) assessed by geophysical investigations, Permafrost Periglac., 18, 351-367, 2007.

Humlum, O.: Active layer thermal regime at three rock glaciers in Greenland, Permafrost Periglac., 8, 383-408, 1997.

Humlum, O.: Rock glaciers on the Faeroe Islands, the north Atlantic, J. Quaternary Sci., 13, 293-307, 1998a.

Humlum, O.: The climatic significance of rock glaciers, Permafrost Periglac., 9, 375-395, 1998b.

Huntington, T. G.: Evidence for intensification of the global water cycle: Review and synthesis, J. Hydrol., 319, 83-95, doi:10.1016/j.jhydrol.2005.07.003, 2006.

Ikeda, A. and Matsuoka, N.: Degradation of talus-derived rock glaciers in the Upper Engadin, Swiss Alps, Permafrost Periglac., 13, 145-161, doi:10.1002/Ppp.413, 2002.

Ikeda, A. and Matsuoka, N.: Pebbly versus bouldery rock glaciers: Morphology, structure and processes, Geomorphology, 73, 279296, 2006.

Ikeda, A., Matsuoka, N., and Kääb, A.: Fast deformation of perennially frozen debris in a warm rock glacier in the Swiss Alps: An effect of liquid water, J. Geophys. Res., 113, doi:10.1029/2007JF000859, 2008.

IPCC: Climate Change 2007: The Physical Science Basis. Contribution of Working Group I to the Fourth Assessment Report of the Intergovernmental Panel on Climate Change, edited by: Solomon, S., Qin, D., Manning, M., Chen, Z., Marquis, M., Averyt, K. B., Tignor, M., and Miller, H. L., Cambridge University Press, Cambridge, 2007.

Isaksen, K., Odegard, R. S., Eiken, T., and Sollid, J. L.: Composition, flow and development of two tongue-shaped rock glaciers in the permafrost of Svalbard, Permafrost Periglac., 11, 241-257, 2000.

Jorgenson, M. T., Shur, Y. L., and Pullman, E. R.: Abrupt increase in permafrost degradation in Arctic Alaska, Geophys. Res. Lett., 33, L02503, doi:10.1029/2005GL024960, 2006.

Jorgenson, M. T., Yoshikawa, K., Kanevskiy, M., Shur, Y. L., Romanovsky, V. E., Marchenko, S., Grosse, G., Brown, J., and Jones, B.: Permafrost Characteristics of Alaska, Ninth International Conference on Permafrost, University of Alaska Fairbanks, 29 June - 3 July 2008, Extended Abstr., 121-122, 2008.

Kääb, A., Haeberli, W., and Gudmundsson, G. H.: Analysing the creep of mountain permafrost using high precision aerial photogrammetry: 25 years of monitoring Gruben Rock Glacier, Swiss Alps, Permafrost Periglac., 8, 409-426, 1997.

Kääb, A., Reynolds, J., and Haeberli, W.: Glacier and Permafrost Hazards in High Mountains; in: Global Change and Mountain Regions, edited by: Huber, U. M., Bugmann, H. K. M., Reasoner, M. A., 23, Springer Netherlands, 225-234, 2005.

Kääb, A., Chiarle, M., Raup, B., and Schneider, C.: Climate change impacts on mountain glaciers and permafrost, Global Planet. Change, 56, vii-ix, 2007a.

Kääb, A., Frauenfelder, R., and Roer, I.: On the response of rockglacier creep to surface temperature increase, Global Planet. Change, 56, 172-187, 2007b.

Krainer, K. and He, X.: Flow velocities of active rock glaciers in the Austrian Alps, Geografiska Annaler: Series A, Phys. Geography, 88, 267-280, 2006. 
Kreig, R. A. and Reger, R. D.: Air-photo analysis and summary of landform soil properties along the route of the trans-alaska pipeline system, Alaska Division of Geological and Geophysical Surveys, Anchorage, 149, 1982.

Lambiel, C., Delaloye, R., Strozzi, T., Lugon, R., and Raetzo, H.: ERS InSAR for Assessing Rock Glacier Activity, in: Ninth International Conference on Permafrost, edited by: Kane, D. L., Hinkel, K. M., Fairbanks: University of Alaska Fairbanks, 10191024, 2008.

Lewkowicz, A. G. and Harris, C.: Morphology and geotechnique of active-layer detachment failures in discontinuous and continuous permafrost, northern Canada, Geomorphology, 69, 275-297, 2005.

Marchenko, S. S., Gorbunov, A. P., and Romanovsky, V. E.: Permafrost warming in the Tien Shan Mountains, Central Asia, Global Planet Change, 56, 311-327, 2007.

Matsuoka, N. and Humlum, O.: Monitoring periglacial processes: New methodology and technology, Permafrost Periglac., 14, 299-303, doi:10.1002/Ppp.461, 2003.

Matsuoka, N., Ikeda, A., and Date, T.: Morphometric analysis of solifluction lobes and rock glaciers in the Swiss Alps, Permafrost Periglac., 16, 99-113, doi:10.1002/Ppp.517, 2005.

Molnia, B. F.: Late nineteenth to early twenty-first century behaviour of Alaskan glaciers as indicators of changing regional climate, Global Planet. Change, 56, 23-56, doi:10.1016/j.gloplacha.2006.07.011, 2007.

Nolan, M., Arendt, A., Rabus, B., and Hinzman, L.: Volume change of McCall Glacier, Arctic Alaska, USA, 1956-2003, Ann. Glaciol., 42, 2005, 42, 409-416, 2005.

Riff, F., Lambiel, C., and Oppikofer, T.: Contribution of Terrestrial Laser Scanning for Studying the Creep of Mountain Permafrost, Extended abstr., in: Ninth International Conference on Permafrost, Kane, D. L. and Hinkel, K. M., Fairbanks: University of Alaska Fairbanks, 255-257, 2008.
Roer, I., Haeberli, W., Avian, M., Kauffman, V., Delaloye, R., Lambiel, C., and Kääb A.: Observations and Considerations on Destabilizing Rock Glaciers in the European Alps, in: Ninth International Conference on Permafrost, editd by: Kane, D. L., Hinkel, K. M., Fairbanks: University of Alaska Fairbanks, 15051510, 2008.

Romanovsky, V. E., Burgess, M., Smith, S., Yoshikawa, K., and Brown, J.: Permafrost temperature records: indicators of climate change, EOS, AGU Transactions, 83, 589-594, 2002.

Romanovsky, V. E., Sazonova, T. S., Balobaev, V. T., Shender, N. I., and Sergueev, D. O.: Past and recent changes in air and permafrost temperatures in eastern Siberia, Global Planet. Change, 56, 399-413, 2007.

Romanovsky, V. E., Smith, S. L., and Christiansen, H. H.: Permafrost Thermal State in the Polar Northern Hemisphere during the International Polar Year 2007-2009: a Synthesis, Permafrost Periglac., 21, 106-116, doi: 10.1002/Ppp.689, 2010.

Smith, S. L., Romanovsky, V. E., Lewkowicz, A. G., Burn, C. R., Allard, M., Clow, G. D., Yoshikawa, K., and Throop, J.: Thermal State of Permafrost in North America: A Contribution to the International Polar Year, Permafrost Periglac., 21, 117-135, doi:10.1002/Ppp.690, 2010.

Swanger, K. M. and Marchant, D. R.: Sensitivity of ice-cemented Antarctic soils to greenhouse-induced thawing: Are terrestrial archives at risk?, Earth Planet. Sci. Lett., 259, 347-359, 2007.

Wahrhaftig, C. and Cox, A.: Rock Glaciers in the Alaska Range, Geol. Soc. Am. Bull., 70, 383-436, 1959. 